\title{
The Relationship Between Self - Efficacy and Readiness for Self - Directed Learning of Students at Vietnam University
}

\author{
Truong Phan Nguyen Dong (Corresponding author) \\ Gifted and Talented Education, Program Department, Vinschool Education System \\ No 7, Bang Lang 01 street, Vinhomes Riverside residency, Viet Hung ward, Long Bien \\ District, Hanoi Capital, Vietnam
}

Tel: 840937960567 E-mail: truongphannguyen.ebkmf@gmail.com

Tuong Nguyen Van

University of Social Sciences and Humanities

Viet Nam National University Ho Chi Minh City

10-12 Đinh Tiên Hoàng, Ben Nghe ward, District 01, Ho Chi Minh City

\author{
Giau Dinh Sang
}

Dong Da primary school, Binh Thanh district, Ho Chi Minh City

217 Nguyen Gia Tri, Ward 25, Binh Thanh, Ho Chi Minh City

Received: August 18, 2021 Accepted: September 9, 2021 Published: September 15, 2021

doi:10.5296/ijld.v11i3.18946ＵRL: https://doi.org/10.5296/ijld.v11i3.18946

\begin{abstract}
The research aims to investigate the readiness of self-directed learning, self-efficacy, and the relationship between them in students at the University of Social Science and Humanities Vietnam National University Ho Chi Minh City. The study was administrated with the self-efficacy scale developed by Schwarzer, R., \& Jerusalem, M. (1993) and the readiness for self-directed learning scale developed by Fisher et al. $(2001,2010)$. The total number of students at the University of Social Sciences and Humanities, Vietnam National University, Ho Chi Minh City was 12,540 students (according to the second term of the academic year
\end{abstract}


2020-2021). This study's sample was calculated with the formula developed by Watson (2001). With a confidence level of $95 \%$ and a variable value of $50 \%$, in the results table of Watson's sample size for a total population of 10,000 to 15,000 people, the sample size for this study ranged from 385 to 390 people. The official sample of 395 students was suitable, which could represent the total population according to Watson (2001). Research results showed that the level of self-efficacy and readiness for self-directed learning among students at the University of Social Sciences and Humanities, Vietnam National University, Ho Chi Minh City was at an intermediate level. In particular, the results indicated that there was a difference between different academic-year students and readiness for self-directed learning. Research results implied that there was a close correlation between self-efficacy and readiness for self-directed learning in students.

Keywords: self - efficacy; readiness for self - directed learning; students, University of Social Science and Humanities Vietnam National University Ho Chi Minh City

\section{Introduction}

\subsection{Concept of Self-Directed Learning}

Self-directed learning is one of the research topic attracting many scholars' interests. As far as this research considered, the concept of self-directed learning was first stated by Knowles (1975). According to Knowles (1975) self-directed learning or self - study, is an active individual process, with or without the help of others in understanding their own learning needs, self-identifying resources to learn, self-select and implement appropriate learning strategies and evaluate their own learning outcomes. This definition was cited by many researchers including Long (1987, 1989, 1991); Brockett and Hiemstra (1991); Candy (1991); Garrison (1997). Besides that, scholars also contributed to theory of self-directed learning in such aspects as: self-directed learning is a psychological control; the parallel effect of individual psychology and pedagogical psychology includes psychological self-control, motivational needs, resource identification strategy (Long, 1987; 1989; 1991); Self-directed learning is responsible for learning and for learners themselves (Brockett and Hiemstra, 1991); Self-directed learning is self-directed that was not necessarily taken place in a classroom environment; Self-directed learning was not as equally as it was in different situations and majors (Candy, 1991); Self-directed learning is self-management, self-monitoring, self-motivation (Garrison, 1997). Within the scope of this research, the concept of self-directed learning of Knowles (1975) was applied.

\subsection{Concept of Self-Efficacy}

Bandura (1986) suggested that the self-efficacy structure includes people's assessment of their own organizational abilities and their ability to perform the necessary actions to achieve their behavioral goals, motion given in advance. Self-efficacy has nothing to do with the skills a person has, but rather with an appreciation of what they can do with whatever skills they possess. According to researchers Bandura (1977, 1982, 1989); Schunk (1989a, 1989b); Zimmerman et al. (1992), self-efficacy affects several aspects of behavior that are significant for learning. Among these are the choice of activities a student undertakes, the effort put forth, 
and the persistence in completing the task.

\subsection{Relation of Self-Efficacy and Self-Directed Learning}

Within our scopes of research, directed research on the relationship between self-efficacy and self-directed learning was quite limited. Researches mostly focused on the study of self-efficacy in relation to other educational objectvies such as schooling environment, learning behaviors. However, amongst the studies that believe in self-efficacy and self-directed learning, self-directed learning and self-efficacy were interrelated. Lema et al (2007) investigated the relationship between self-efficacy and self-directed learning of students at the School of Hospitality. The study used the general self-efficacy scale developed by Schwarzer et al (1993). Research results showed that self-efficacy was an important predictor of self-learning ability. Turan et al (2008) examined the influence of self-directed learning on self-efficacy and critical thinking. The study was conducted on a sample of 419 students from the School of Physics and Sports of Erciyes University, Turkey. The results indicated that self-directed learning widely affects not only self-efficacy, critical thinking but other aspects of education and training. Saeid et al (2016) examined the relationship between self-directed learning and self-efficacy, learning motivation in students. The study was conducted with a sample of 322 students from Payamnoor University in the academic years 2014-2015. The scale administrated was the self-directed learning scale developed by Gugliemino (1978), the self-efficacy scale by Morgan - Janknis (1999). Research results showed that there was a strong correlation between self-directed learning and self-efficacy.

\section{Method}

\subsection{Sample}

The sample was a convenient random probability sample. The sample size was calculated according to the formula by Watson (2001). According to Watson (2001), with the total population of the University of Social Sciences and Humanities, Vietnam National University Ho Chi Minh City is approximately 12,540 students (in academic year, $2020-2021$ ), the research sample applied calculation of Waston (2001) with confident level at 50\%, the sample size varies from 385 to 390 participants. The official survey sample was 395 students. There were 106 male students and 289 female students. The survey was conducted from March to April 2021.

\subsection{Instruments}

\section{Fisher et al (2010) Readiness for self-directed learning scale}

The readiness for self-directed learning scale was initially developed as an alternative for Guglielmino's (Guglielmino, L.M. 1977). With the desire to alter the scale developed by Guglielmino (1977), Fisher et al $(2001,2010)$ have developed a scale in oder to measure readiness for self-directed learning. The scale for readiness for self-directed learning by Fisher et al. (2001) had 40 items. In 2010, Fisher et al revised and proposed a new version short scale with 29 items including 3 factors: Self-management; Desire for Learning; Self-control. Cronbach Alpha index was 0.87 for the total scale (2010); 0.857 for 
Self-management, 0.847 for Desire for learning; 0.830 for the Self-control. Participants were asked to indicate the degree each item reflecting their own characteristics by using a five-point Likert scale at which 1 indicated "strongly disagree" and 5 indicated "strongly agree".

\section{Schwearzwer and Jerusalem (1993) General self-efficacy scale}

This study also used the General self-efficacy scale (GSE) developed by Schwarzer and Jerusalem (1993) to find out the degree of self-efficacy of students. This scale consists of 10 items that measure the strength of an individual's belief in their ability to meet and control the demands and challenges of the environment. This scale has been adapted into 28 different languages on the basis of German and English versions. On the other hand, this scale has been used in a large number of research projects and has a fairly consistent Cronbach's Alpha coefficient from 0.75 to 0.91 (Urte Scholz et al., 2002).

In this study, the process of language translation and Vietnamization of the two scales was conducted in 4 steps: 1/Translation from English to Vietnamese and translation from Vietnamese to English by different experts with different qualifications at a proficient level of English; 2/ Evaluation of experts who are not involved at the translation stage; 3/ Interview and do experimental research with 15 students to check reading comprehension and survey time; 4/ Completing the official Vietnamese scale.

\section{Results}

\subsection{Cronbach Alpha Analysis and Exploratory Factors Analysis}

\section{Fisher et al (2010) Readiness for self-directed learning}

The study with the participation of 395 respondents on the scale of readiness for self-directed learning developed by Fisher et al (2010) has the Cronbach Alpha index of the factor groups respectively 0.91 (Self-management), 0.829 (Desire for learning), 0.879 (Self-control). The EFA analysis showed that the KMO was 0.820 ; Initial Eigenvalues was 1,865 at 3 factors. Therefore, according to the results, the 29 - item scale of Fisher et al achieved sufficient reliability and validity in this study.

The result revealed that self - efficacy scale's Cronbach Alpha was 0.927 with the total variable correlation varied from $0.6-0.843$. The KMO from the study was 0.886 ( $\mathrm{Sig}=$ 0.000 ) with factors loading varied from 0.664 to 0.888 . With a scale of self-efficacy, this was a 5-level Likert scale, in which the lowest score for 10 items is 10 points and the highest is 50 points. The higher the total score is, the higher the self-efficacy of the participants is. In this study, we divided by levels, from 10 points to 20 points is a low level of self-efficacy, from 21 points to 40 points is the average level of self-efficacy and from 41 to 50 points is a high level of self-efficacy.

\subsection{Self-Efficacy of University of Social Science and Humanities'students}

Research showed that the average self-efficacy of students at the University of Social Sciences and Humanities was 38.81 points/50 points, of which, the lowest score is 22 points, 


\section{Macrothink}

International Journal of Learning and Development

ISSN 2164-4063

2021, Vol. 11, No. 3

the highest score is 50 points. For this scale, the higher the mean score was, the higher the confidence in self-efficacy was. Accordingly, the self-efficacy of students in this study was quite high, higher than the research results of Feldman (2015) with the average student's self-efficacy of 31.36. (Std.D = 3.83). This study revealed that the average confidence level of male students in self-efficacy was 39.56 (Std.D $=6.91$ ), average confidence in self-efficacy of female students was 38.54 (Std.D = 6.88). There was no statistically significant difference between male and female students in self-efficacy. In which, there were 237 students with a total score of 21 to 40 points, and 158 students with a total score of 41 points or more.

Table 1. The differences in self-efficacy between male and female students

\begin{tabular}{llll}
\hline & Male & Female & $\begin{array}{l}\text { Meaningful } \\
\text { level p }\end{array}$ \\
\cline { 2 - 4 } & Mean (Std.D) & Mean (Std.D) & $0.193(>0.05)$ \\
\hline Self - efficacy & $39.56(6.91)$ & $38.53(6.88)$ & \\
\hline
\end{tabular}

In addition, the mean score of self-efficacy among first-year students was 39.24 (Std.D= 4.54); for 2nd year students was 38.75 (Std. $\mathrm{D}=6.15$ ); for 3rd year students was 39.41 (Std.D $=7.34)$ and for 4 th year students was $37.56($ Std.D $=7.21)$. Independent T-test showed that Levene'test revealed a value of 0.889 and a sig T-Test value was $0.193>0.05$, the results indicated that there was no statistically significant difference in self-efficacy between male and female students. The One-Way Anova test showed that the Leven' test gave a value of $0.002(<0.05)$ and the Sig Welch test was $0.242(>0.05)$. Thus, there was no difference between self-efficacy beliefs in different school years.

Table 2. The results of the analysis the difference between students in self - efficacy

\begin{tabular}{|c|c|c|c|c|c|}
\hline \multirow[b]{2}{*}{ Academic years } & First year & Second year & Third year & Fourth year & \multirow[b]{2}{*}{$\mathbf{F}$} \\
\hline & $\begin{array}{l}\text { Mean } \\
\text { (Std.D) }\end{array}$ & $\begin{array}{l}\text { Mean } \\
\text { (Std.D) }\end{array}$ & $\begin{array}{l}\text { Mean } \\
\text { (Std.D) }\end{array}$ & $\begin{array}{l}\text { Mean } \\
\text { (Std.D) }\end{array}$ & \\
\hline Self - efficacy & $39.24(4.54)$ & $38.75(6.15)$ & $39.41(7.34)$ & $37.56(7.21)$ & 1.53 \\
\hline
\end{tabular}

\subsection{Readiness for Self-Directed Learning of University of Social Science and Humanities' Students}

The One-Way Anova test indicated the Sig index of the self-management and the Sig index of the self-control factor, respectively, were 0.001 and $0.006(<0.05)$. The results suggested a statistically significant difference between different academic-year students in terms of 
self-management and self-control. After Post Hoc analysis with Tamhane and LSD tests employed, the results revealed that there was a difference between different academic-year students in term of self-management. For more specific, the Sig index of self-management is 0.001 between 4th and 3rd-year students; 0.002 between 4th and 1st-year students; 0.038 between 3rd and 2nd-year students; 0.014 between 1st year and 2nd-year students (less than 0.05). Besides that, the results also pointed out that there was a statistically significant difference in self-control amongst the 3rd and 4th-year students. For more specific, the Sig index for self-control was 0.06 between 3rd and 4th-year students (less than 0.05). In comparison with the average score of each component within readiness for self-directed learning, the results showed that first-year students have the highest average score on self-management (3.67); and fourth-year students have the lowest mean score on self-management (3.14). In addition, the average score of self-management in students at the University of Social Sciences and Humanities, Vietnam National University, Ho Chi Minh City was 3.36. Regarding self-control, third-year students had the highest average score (4.13); fourth-year students had the lowest mean score (3.85). The average score of the self-control factor of all students was 4.02. In addition, desire for learning had an average score of 4.25 in all students at the University of Social Sciences and Humanities, Vietnam National University, Ho Chi Minh City. In which, the results show that there was no difference between school years, the average score in each school year is $4.3 ; 4.15 ; 4.3 ; 4.2$, respectively.

Table 3. Differents academic - year students and factors of readiness for self-directed learning

\section{Readiness for self - directed learning}

\begin{tabular}{llll}
\cline { 2 - 4 } Academic years & Self-management & Desire for learning & Self-control \\
\cline { 2 - 4 } & Mean (Std.D) & Mean (Std.D) & Mean (Std.D) \\
\hline First year & $3.67(0.72)$ & $4.3(0.59)$ & $4.11(0.48)$ \\
Second year & $3.26(0.72)$ & $4.15(0.57)$ & $3.96(0.53)$ \\
Third year & $3.47(0.82)$ & $4.31(0.58)$ & $4.13(0.64)$ \\
Forth year & $3.15(0.76)$ & $4.21(0.56)$ & $3.84(0.67)$ \\
Total & $3.36(0.79)$ & $4.25(0.57)$ & $4.02(0.62)$ \\
F & $5.516^{* *}$ & 1.887 & $4.750 * *$ \\
\hline Note. ** when & $p<0.05$. & &
\end{tabular}

3.4 The Relationship between Self-Efficacy and Readiness for Self-Directed Learning of University of Social Science and Humanities'students. 


\section{Macrothink}

The Pearson test was administrated to the research to evaluate the correlation between self-efficacy and readiness for self-directed learning amongst students at the University of Social Sciences and Humanities, Vietnam National University Ho Chi Minh City. The result revealed that there was a strong correlation between self-efficacy and components of readiness for self - directed learning and readiness for self - directed learning in general (Pearson correlation index varied from $0.447-0.624$ with Sig 2 - tailed indexes $<0.005$ ). The strongest correlation was between self-efficacy, and self-control (Pearson correlation $=0.617$ ) and the weakest correlation was between self-efficacy and self-management (Pearson correlation $=0.447$ ). To evaluate the correlation and impacts of self-efficacy and readiness for self-directed learning, the research was administrated to single regression test.

Table 4. Correlations and regression between self - efficacy and readiness for self - directed learning amonst University of Social Science and Humanities, Vietnam National University Ho Chi Minh City

\begin{tabular}{lll}
\hline Readiness for self - directed learning & Pearson correlation & Regression \\
\hline Self - management & $0.447^{* *}$ & $0.198^{* * *}$ \\
Desire for learning & $0.534^{* *}$ & $0.283^{* * *}$ \\
Self - control & $0.617^{* *}$ & $0.380^{* * *}$ \\
Readniess for self - directed learning & $0.624^{* *}$ & $0.387^{* * *}$
\end{tabular}

Note. $* *$ when $p<0.05$, *** when $p<0.005$.

The results indicated that self - efficacy gives impacts significantly on readiness for self-directed learning. The results revealed that self-efficacy accounted for $38.7 \%$ of changes in readiness for self-directed learning. Besides that, self-efficacy also accounted for $38 \%$ and $28.3 \%$ in self-control and desire for learning, respectively. Self-efficacy shows the least impact and changes in self-management factors (only accounted for $19.8 \%$ of changes in readiness for self-directed learning).

\section{Discussion and conclusion}

In general, self-efficacy has a significant impact on the readiness for self-directed learning of students at the University of Social Sciences and Humanities of Ho Chi Minh City. Self-efficacy has the greatest impact on the self-management factor. The results of this study are quite like those of Lema et al (2007), Turan et al (2008), and Saeid et al (2016). The above studies all show a significant impact from self-efficacy to learners' readiness for self-directed learning. In particular, the factor of self-efficacy has a profound influence on self-control. From the above research results, the managers of the University of Social Sciences and Humanities of Ho Chi Minh City should focus on activities to improve student's self - efficacy, thereby training self-directed learning for students. Especially, students of 


\section{Macrothink}

International Journal of Learning and Development

ISSN 2164-4063

2021, Vol. 11, No. 3

first- and fourth-years students figures indicated that university director should focus more on fostering students' self-control and self-management.

\section{References}

Bandura, A. (1977). Self-efficacy: toward a unifying theory of behavioral change. Psychological Review, 84, 19-1215. https://doi.org/10.1037/0033-295X.84.2.191

Bandura, A. (1982). Self-efficacy mechanism in human agency. American Psychologist, 37, 122-147.

Bandura, A. (1986). Social foundations of thought and action: a social cognitive theory. Englewood Cliffs, NJ: Prentice-Hall. https://doi.org/10.1037/0003-066X.37.2.122

Bandura, A. (1989). Human agency in social cognitive theory. American Psychologist, 44, 1175-1184.

Bandura, A. (1997). Self-efficacy: the exercise of control. New York: Freeman. https://doi.org/10.1037/0003-066X.44.9.1175

Brocket, R. \& Hiemstra, R. (1991). Self-direction in adult learning: perspectives on theory, research, and practice. London \& New York: Routledge \& Keagan Paul.

Brookfield, Stephen (1986). Understanding and facilitating adult learning. San Francisco, CA: Jossey-Bass.

Brookfield, Stephen (1987). Developing critical thinkers: challenging adults to explore alternative ways of thinking and acting. San Francisco, CA: Jossey-Bass.

Brookfield, Stephen (1993). Self-directed learning, political clarity, and the critical practice of adult education. Adult Education Quartely, 43, no 4 (Spring 1993), 227-242. https://doi.org/10.1177/0741713693043004002

Candy, P. C. (1991). Self-Direction for Lifelong Learning (p. 567). San Francisco: Jossey-Bass. https://doi.org/10.1177/074171369204200307

Garrison, D. R. (1992). Critical thinking and self-directed learning in adult education. Adult Education Quartely, n2, 102-116.

Garrison, D. R. (1997). Self-Directed Learning: Toward a Comprehensive Model. Adult Education Quarterly, November 1997. https://doi.org/10.1177/074171369704800103

Guglielmino, L. M. (1977), Development of the self-directed learning readiness scale. Unpublished Doctoral Dissertation (University of Georgia. Dissertation Abstracts International 38, 6467A).

Jerry Jinks and Vicky Morgan, (1999), Children's Perceived Academic Self-Efficacy: An Inventory Scale. The Clearing House, 72(4), 224-230. https://doi.org/10.1080/00098659909599398 


\section{I Macrothink}

International Journal of Learning and Development

ISSN 2164-4063

2021, Vol. 11, No. 3

Lema, J. D., \& Agrusa, J. (2007). Self-Efficacy, Industry Experience, and the Self-Directed Learning Readiness of Hospitality Industry College Students. Journal of Teaching in Travel \& Tourism, 6(4), 37-50. https://doi.org/10.1300/J172v06n04_03

Long, H. (1987), Self-directed learning and learning theory. Unpublished paper presented at Commission of Professors Conference, Washington, D.C.

Long, H. (1989), Self-directed learning: emerging theory and practice. In Huey Long \& Associates, Self-directed learning: emerging theory \& practice. Norman, Oklahoma: Oklahoma Research Center for Continuing Professional and Higher Education, University of Oklahoma, 1-11.

Long, H. (1991). Self-directed learning: consensus and conflict. In Huey Long \& Associates, Self-directed learning: consensus \& conflict. Norman, Oklahoma: Oklahoma Research Center for Continuing Professional and Higher Education, University of Oklahoma, 1-9.

Malcolm, S. K. (1975). Self-directed Learning, A guide for learner and teachers. Association Press, 1975, Follett Publishing company, Chicago.

Mirzawati, N., Neviyarni, N., Rusdinal, R. (2020). The Relationship between Selfefficacy and Learning Environment with Students' Self-directed Learning. Jurnal Aplikasi IPTEK Indonesia, 4(1), 37-42. https://doi.org/10.24036/4.14343

Murray, F., Jennifer, K., \& Grace, T. (2001), Development of a self-directed learning readiness scale for nursing education. Nurse Education Today, 21, 516-525. https://doi.org/10.1054/nedt.2001.0589

Murray, J. F., \& Jennie, K. (2010). The self-directed learning readiness scale for nursing education revisited: A confirmatory factor analysis. Nurse Education Today, 30, 44-48. https://doi.org/10.1016/j.nedt.2009.05.020

Saeid, N., \& Eslaminejad, T. (2016). Relationship between Student's Self-Directed-Learning Readiness and Academic Self-Efficacy and Achievement Motivation in Students. International Education Studies, 10(1), 225. https://doi.org/10.5539/ies.v10n1p225

Schunk, D. H. (1989a). Self-efficacy and achievement behaviors. Educational Psychology Review, 1, 173-208. https://doi.org/10.1007/BF01320134

Schunk, D. H. (1989b). Social cognitive theory and self-regulated learning. In B.J. Zimmerman \& D.H. Schunk (Eds.), Self-regulated learning and academic achievement: theory, research and practice (pp. 186-213). New York: Springer-Verlag. https://doi.org/10.1007/978-1-4612-3618-4_4

Schwarzer, R., \& Jerusalem, M. (1993). Measurement of Perceived Self-Efficacy: Psychometric Scales for Cross-Cultural Research. Berlin: Freie University.

Susan, L. S., \& Ralph, G. B. (2010), Development of the PROSDLS: A Measure of SelfDirection in Learning Based on the Personal Responsibility Orientation Model. Adult Education Quarterly, 61(2), 161. American Association for Adult and Continuing Education. 


\section{Macrothink}

https://doi.org/10.1177/0741713610380447

Turan, M. B., \& Koç, K. (2018). The Impact of Self-Directed Learning Readiness on Critical Thinking and Self-Efficacy among the Students of the School of Physical Education and Sports. International Journal of Higher Education, $7(6), \quad 98$. https://doi.org/10.5430/ijhe.v7n6p98

Urte Scholz, Benicio Gutiérrez Doña, Shonali Sud, and Ralf Schwarzer (2002). Is General Self-Efficacy a Universal Construct? Psychometric Findings from 25 Countries. European Journal of Psychological Assessment, 18(3), 242-251, https://doi.org/10.1027//1015-5759.18.3.242

Watson, J. (2001). How to Determine a Sample Size: Tipsheet \#60 (University Park, PA: Penn State Cooperative Extension).

Zimmerman, B. J., Bandura, A., \& Martinez-Pons, M. (1992). Self-motivation for academic attainment: the role of self-efficacy beliefs and personal goal setting. American Educational Research Journal, 29, 663-676. https://doi.org/10.3102/00028312029003663

\section{Copyright Disclaimer}

Copyright for this article is retained by the author(s), with first publication rights granted to the journal.

This is an open-access article distributed under the terms and conditions of the Creative Commons Attribution license (http://creativecommons.org/licenses/by/4.0/). 